\title{
Research on Stimulating Effect of International Trade on Chinese Regional Economy
}

\author{
Hong LV ${ }^{1, a}$ \\ ${ }^{1}$ Nanyang Institute of Technology of E-Commerce, Nanyang, Henan Province, 473004 \\ ${ }^{\mathrm{a}}$ email
}

Keywords: International Trade, Regional Economy Development, Influence and Development

\begin{abstract}
With the change and the development of economic globalization and society region, the development impact of international trade on our entire regional economic is also increasingly stand out, the so-called regional economy, its development have their own certain measure, we generally mean the total regional economic growth and increased welfare in a certain period of time, as well as the corresponding ideology, economic growth structure, income distribution adjustment and improvement as its measure methods. Therefore, we focused on the characteristics of the regional economy, research on how to better carry out the advantages of international trade to promote regional economic good overall development, therefore, the contribution of international trade to the regional economy development and we have to rely on the measure index for improvement and implementation.

With the accelerated pace of reform and opening up, since our country joined the WTO, a lot of places has gradually developed into an internationally competitive economic zones, but whether the development of these regional economic is with the complicated relationship between international trade, we still need combined with the actual situation to research and analysis. Although the economy of China has been greatly improved and developed, but the unified mature domestic market simply did not form, the domestic regional economy is mainly based on subsistence-based and cannot achieve the optimal allocation of resources, as many there are various places where economic protectionism, so our regional development planning rarely able to develop the local economy and international trade advantages linked. So let regional economic development in various parts of our country had a great difference, but for the entire international trade of regional economic development impact is minimal, so we're going through this research, analysis the basic theory of international trade promoting economic development and the impact of regional economic development in international trade is analyzed, and promote the countermeasures to promote region's economic development for the entire international trade advantages.
\end{abstract}

\section{Introduction}

The main theme of national economic development will always be open to the rapid development of international community today. A country and a region want to develop, especially the development of the economy, we should actively develop and integrate into the world community, can not be long it is closed, of seclusion, only the implementation of the open policy, so that the regional economy to participate in international trade were to be able to promote the rapid development of regional economy, as a developing country, China's mainland areas in all regions there is a very serious unbalanced regional economic development, competitive industries and the characteristics of each region is different, which requires our own strengths and weaknesses profound understanding of their strategy formulation, regional macro-economic and onlookers from two aspects formulate development strategies, the use of international trade in its own share of advantages, the development of national economy.

\section{The Meaning and Context of the Impact of International Trade on the Regional Economy}

The relationship between the international trade and regional economies growth although has been one of the hottest topics in the world economic community, but so far whether the international 
trade would affect regional economic development, as well as ways and means what this influence is, there is still no a unified theory, at our different levels of economic development and economic structure and policy, international trade for our regional economic development is not the same, so this leads to people for regional economic growth impact on international trade We have a different view. With the economic development of the world, each country's economic transactions with each other frequently up, the whole world is slowly towards economic integration, each country will be open as much as possible in economic development, and actively integrate into the global economy to go, Therefore, in today's situation of economic globalization, the international trade to promote regional economic development is inevitable.

China, as a big developing country, is one of the most important players in world economic integration process, since the reform and opening up two decades between the average GDP growth rate of nine percent, dependence on foreign trade increased to one hundred more than sixty points, so that international trade is the direct driving force to promote China's economic development.

So in our economic background, we are promoting the role of international trade within the region for economic development, mechanisms, pathways and effects have important theoretical significance, but at the same time to affect the entire international trade on regional economic growth as well as through what way to grasp the advantages of international trade also has an important significance.

\section{The Domestic and International Research on the Subject}

The International Research. For the aspects of the relationship of international trade and regional economic growth, many scholars have carried out their research, it is divided into two major factions, namely in favor of and questioned.

First proposed specialization will increase labor productivity and increasing returns to scale are masters of classical economics, Adam Smith, in his view of international trade for the economic development of the region there is a role in promoting. Ricardo's theory of comparative advantage also believes that the international trade involved in regional economic development is of positive significance; and representatives of the Trade Development System Analysis Theory John Mueller by promoting the role of trade in economic research and analysis, pointed guarantee the rapid development of the foundation of world peace and human progress is trade. Many scholars after their theory of a more profound analysis and research, many scholars are agreed world trade, the development of international trade is regional economic development has a positive role in promoting the.

Of course, in addition to the positive attitude of these scholars, many scholars of international trade on the role of the Regional Economic Development skeptical, the famous economist Liszt believes that the role of international trade for the whole economic development can not be generalized, it the role at different times is not the same, after World War II, many of the nation became independent, many anti-trade theory began to emerge, a representative of a positive cycle theory of causality Myrdal, Prebisch center theory etc. these theories are that the international trade will not only fail to promote economic growth in developing countries but to the entire economic development of certain side effects.

With economic development, many new theories have been proposed to the 1980's, when new growth theory to our business development issues studied, that our economy is endogenous variable of the decision, and not because the role of external factors, which our government to make a variety of decisions and provides for economic changes played a very important role. Generate new growth theory, on the one hand that economic growth comes from new ideas and new technologies, on the other hand extends the classical economics division of labor to promote economic growth point of view. Because the new technology and new ideas have been diffused through international trade, international trade and therefore they are conducive to the promotion of total economic growth.

Domestic Research. Before the reform and opening up, China's international trade has been in a state of stagnation, there are few relevant theoretical research, Professor Zhang Peigang in our 
country at that time even if it is relatively early for trade relations throughout the developing and developed countries for the relevant analysis; Professor Zheng Youshou from the historical perspective of the situation related to international trade and economic development.

But after the reform and opening period of development and international trade into the country very quickly, and adapt to the changing situation, China's a lot of theory began to emerge slowly, after the 1990s, our theory has been start on international trade related influence regional economic development were discussed, some of our scholars related finding from trade experience a lot of other countries, international in order to find a suitable for China's growing economy of the road, some scholars from economic liberalization conditions for the crowd to find factors, accumulation of capital, income distribution and utilization of human resources and technological progress and institutional and industrial structure; also scholars from the Chinese domestic market conditions distorted by the entire international relations and international trade policy and openness to conducting impact of international trade.

\section{The Mechanism of International Trade Promotes the Economic Growth}

Through theoretical development of domestic and international economic growth prior to the review, we can see that no matter what kind of summary of economic and trade theory, most of the theory of international trade and buy our role in promoting regional economic development of all have a positive attitude, so we believe that the international trade under certain conditions for our regional economic development is promoted, and this role is mainly reflected in the static and dynamic benefits of international trade to promote regional economic development.

The International Trade Static Interest Promotes the Increases of Output. Static benefits of international trade are mainly on the basis of promoting the efficient allocation of resources and to facilitate international comparative advantages of each country on the refinement of the division of labor, so that the output increases. Every country according to their own national characteristics produce a comparative advantage, through international trade, so the demand for the product continues to increase, so will encourage the consumption level, various countries continued to expand international trade, international trade this division of labor brought about by a static thing interests.

Static benefits of international trade can also promote a country full use of internal resources, so that countries with different strengths, we can get some use, but because of different levels of openness and development of each country, so that will lead to unused resources so our country to international trade can open a relatively free and open environment, increase the country's economic development and progress.

The International Trade Dynamic Interest Promotes the Increases of Economic. Dynamic benefits of international trade mainly in obtaining economies of scale, promote technological progress and deliver economic growth, we can achieve dynamic interests, to further promote the country's economic growth.

International trade can expand external markets enhance the economic efficiency of each country's international trade channels will promote external demand their own country, and further expand its internal market demand, with the expansion of the scale, put on each unit of product the cost will be lower than before, so that will promote domestic economic development. At the same before and after the different economies of scale if implemented, then the cost will be lower than first realized unrealized, they will be more competitive in international trade. So how we use to their advantage in international trade as soon as possible the formation of economies of scale is a very important significance.

One of the effects of technological progress and innovation is also knowledge of international trade, from the classical school of economics had been full attention, technological progress is the ultimate source of economic growth. This effect is a chain reaction, we must stimulate innovation in the industry, on the one hand to expand the export market, improve product quality, enhance communication and advanced technology. Of course, the role of international trade, not only this, but he was able to promote our country and other countries of the industry have a ripple effect, 
improving product quality and quantity of the market and improve GNP.

Dynamic benefits of international trade but also be able to transfer benefits of economic growth line, the same product we can cooperate with each other in different countries, were completed; others because mastered the core technology, can be used as a central country of primary products in the processing, such as the central government for the entire product requirements and increased demand, so it will simultaneously promote the production and development of the peripheral countries.

\section{Conclusion}

We can be sure that international trade is constant to promote the economic development, but his ways and means as well as the size of the role of the regional economic development in different economic development trade theory is not the same, the regional economy as a economic entities, development theory has gone through a lot in the process, now in a peaceful and stable social environment, international trade, regional economic development has played a decisive role, because contact with the world economy and the world economy more to the larger, all economies are impossible in this environment is a long-closed environment, maintain the closed state.

International Trade for regional economic development is of great impact, we passed the whole international trade for the regional economy of the static and dynamic comparative interests, able to draw international business through some of the demand for various products the direction of investment guidelines and more ways of regional economic development be affected, and the regional division of labor, factor accumulation, but also of the economic structure, improve the operational mechanism of promotion has become its main mechanism of action. On this basis, from the macro and micro levels of domestic economic region studied how to use the advantages of regional economic development of international trade measures, and the various aspects of the problems have been studied, a variety of responses. For example, the macro aspects, for improving the industry's planning and economic policy, and in the micro aspects such as increased employment, as well as the brand for the entire region to build applications.

All in all, we are in an open new international environment, under a new open economic model, we need to know how to use their own regional economic advantages, the correct guidance of international trade, for the entire regional development full role and impact, and we want to combine economic and trade environment, the entire international community as well as change and development of the market to make timely adjustments and changes, so that we can in international trade in a favorable position to play a competitive advantage throughout the international market, the realization harmony and stability in our region and the rapid and coordinated economic development. Through our development of regional economic we can integrate into international trade faster and better.

\section{References}

[1] Gou Zhi Qian. The unbalanced regional economic development study [D], Jilin: Northeast Normal University School of Economics, 2007

[2] Gao Guoli, The unbalanced regional economic development theory [M], Beijing: Economic Science Press, 2008

[3] Chen Kaijun. Foreign Trade on Regional Economic Disparity - An Empirical Study of Chinese data [D], Hunan: Hunan University School of Economics, 2005.

[4] He Li.Foreign trade gap with China Regional Economy [J], Finance \& Economics, 2007, (7).

[5] Li Guozhu, Ma Shucai. Differences in regional trade and regional imbalances Development Studies, Business Studies, 2007, (8) 